\title{
Yeast fermented additive enhances broiler growth
}

\author{
Sulhattin Yasar ${ }^{1 *}$, Mustafa Kemal Yegen ${ }^{2}$ \\ ${ }^{1}$ Igdir University, Faculty of Agriculture, Department of Animal Science, Igdir, Turkey. \\ 2 Süleyman Demirel University, Faculty of Agriculture, Department of Animal Science, Isparta, Turkey.
}

\begin{abstract}
We investigated the effects of dietary supplementations of yeast (YFA) or non-yeast fermented additives (NYFA) at 5.0 and $10 \mathrm{~g} \mathrm{~kg}^{-1}$ on the performance parameters and the size of digestive organs of broiler chickens. An isocaloric and isonitrogenous basal diet used as negative control was added with 5.0 or $10.0 \mathrm{~g} \mathrm{~kg}^{-1}$ of YFA or NYFA. Each of five experimental diets was given to broiler chickens kept in three randomized floor pens, each with 21 birds, from one-day old to 42 days old. Although the feed intake of broiler chickens was not significantly influenced by the diets, there were significant increases in weight gain and improvements in feed conversion ratio and carcass yield in broiler chickens fed the diets supplemented with 5.0 and $10 \mathrm{~g} \mathrm{~kg}^{-1}$ of YFA and NYFA. The rate of improved weight gain and feed conversion ratio by the dietary treatments was proportional to their viable yeast counts. The diet containing $10 \mathrm{~g} \mathrm{~kg}^{-1}$ of NYFA was not recommended due to remarkably reduced carcass yield as a result of increased weights of digestive tract. The remaining dietary treatments generally caused a reduced length and relative weight of the digestive tract. Of the dietary treatments, the diet containing $10 \mathrm{~g} \mathrm{~kg}^{-1} \mathrm{YFA} \mathrm{caused}$ a significant increase in digesta viscosity with the diet. Significant growth-promoting effects were obtained from the dietary supplementations of $5.0 \mathrm{~g} \mathrm{~kg}^{-1}$ NYFA or 5.0 and $10 \mathrm{~g} \mathrm{~kg}^{-1}$ YFA.
\end{abstract}

Key Words: broiler, fermentation, microbial additive, yeast

\section{Introduction}

Yeast-containing additives could be used as alternatives to the feed antibiotics due to their beneficial performance and health effects on monogastric animals (Dhama et al., 2015; Wang and Xu, 2008; Dębski et al., 2004), especially under heat stress (Haldar et al., 2011). In poultry, yeast probiotics have been found more effective than other probiotics to improve performance of birds (Reisinger et al., 2012; Yasar and Desen, 2014). Furthermore, a new report testing several probiotics of Lactobacillus spp. showed no favorable effects on broiler performance (Olnood et al., 2015). Nevertheless, the supplementation of the diets with yeast probiotics at 0.15 to $0.3 \%$ have been shown to improve the performance of birds to a level achieved by the use of dietary antibiotic levels (Onifade et al., 1999). It has been recently shown that this kind of effect is due to the bacteriocin-producing

Received: February 20, 2017

Accepted: March 30, 2017

*Corresponding author: sulhattin.yasar@gmail.com

http://dx.doi.org/10.1590/S1806-92902017001000004

How to cite: Yasar, S. and Yegen, M. K. 2017. Yeast fermented additive enhances broiler growth. Revista Brasileira de Zootecnia 46(10):814-820.

Copyright (C) 2017 Sociedade Brasileira de Zootecnia. This is an Open Access article distributed under the terms of the Creative Commons Attribution License (http://creativecommons.org/licenses/by/4.0/), which permits unrestricted use, distribution, and reproduction in any medium, provided the original work is properly cited. effects of yeast probiotics when used single or together with lactic acid bacteria species in the diet of broiler chickens (Chen et al., 2016).

In general, the fermented products are the microbial products of solid-state fermentation (SSF) utilized from generally regarded as safe microorganisms. It is well known that the microbial enzymes and several types of feed probiotic additives are produced through the SSF process, in which the production yield is higher than that in liquid state fermentation (Nigam and Pandey, 2009). In such SSF process, the optimization of fermentation conditions is very important. For instance, an unaffected broiler performance was reported with a feed fermented at the conditions of low water content of $250 \mathrm{~g} \mathrm{~kg}^{-1}$ and $\mathrm{pH}$ above 5.0 without use of microbial inoculants. However, when the feed fermented at the same conditions with the use of microbial inoculants, it comparatively induced improved broiler performance (Chen et al., 2009). This result clearly indicates that low water activity and high $\mathrm{pH}$ values (more than 5.0) are not suitable for the activation of endogenous natural microbiota of the fermenting substrate, in which the addition of exogenous microbial inoculant is necessary. Based on our recent findings (Yasar et al., 2016; Yasar and Gok, 2014), an optimised SSF process using no exogenous microbial inoculation was used to produce fermented products, which improved nutritional value in poultry. These feed materials were also good carriers for direct-fed 
microbial (Saccharomyces spp., and Lactobacillus spp.). The optimization of SSF process in these studies was managed under the conditions of moisture content not less than $600 \mathrm{~g} \mathrm{~kg}^{-1}$ and $\mathrm{pH}$ of less than 5.0 (Yasar et al., 2016; Yasar and Gok, 2014). In these studies, it was shown that the fresh liquid whey could be used instead of water to yield the required amount of moisture content and citrus pomace as acidifying agent for lowering $\mathrm{pH}$.

We herein proposed to determine the efficacy of yeast (YFA) and non-yeast fermented additives (NYFA) produced according to an optimized SSF process in a broiler feeding trial.

\section{Material and Methods}

The study was conducted in Isparta, Isparta Province, Turkey (37 $45^{\prime} 45.536^{\prime \prime} \mathrm{N}$ and $\left.30^{\circ} 33^{\prime} 13.338^{\prime \prime} \mathrm{E}\right)$.

A mixture of cereal grain flour, whey, and tomato pomace was prepared in two batches, each with $40 \mathrm{~kg}$. The ratio of fermentation ingredients used is confidential of an on-going patent application, not provided herein. The first batch of YFA was produced by the inoculation of Saccharomyces cerevisiae at $9 \times 10^{9} \mathrm{cfu}$ (colony-forming unit) per kg, whereas no microbial inoculants were used for the production of second batch of NYFA. Two batches of fermentation were conducted in a 90-L laboratory bioreactor under fixed and controlled conditions for $24 \mathrm{~h}$ at $35{ }^{\circ} \mathrm{C}$, $\mathrm{pH}<5.0$ and $60 \%$ total moisture. Fine powder of rosemary leaves was homogenously mixed with final products before drying. Total titratable acidity of the fermentation product at 0 and $24 \mathrm{~h}$ was measured by the titration of 10 times diluted samples with $0.02 \mathrm{M} \mathrm{NaOH}$ until an endpoint of $\mathrm{pH} 8.2$ was reached and the results were calculated as percentage of the total mass $(\mathrm{w} / \mathrm{w})$. The fermented mixture was immediately dried at $24{ }^{\circ} \mathrm{C}$ for $72 \mathrm{~h}$. The viable cell counts of Saccharomyces spp. in YFA and NYFA and the diets containing YFA and NYFA were enumerated as cfu by a pour plate method (ISO, 2009), using yeast extract dextrose chloramphenicol agar (CGYE) incubated at $35{ }^{\circ} \mathrm{C}$ for $48 \mathrm{~h}$.

Dried YFA and its positive control of NYFA were added to a basal diet (negative control) at 5.0 or $10.0 \mathrm{~g} \mathrm{~kg}^{-1}$ at the expense of wheat grain (Table 1). Thus, these five isocaloric and isonitrogenous diets were tested in a broiler feeding trial, which was approved by the local Animal Ethic committee of 26/02/2013 (tarih ve 01 say1).

Three hundred fifteen one-day-old birds (Ross 308PM), kept on 15 randomized floor pens, each with 21 chicks were fed the diets. The experimental model was of five diets by three randomized pen replicates. The trial lasted from 1 to 42 days of age. Feed and water were freely accessible to the birds. Room temperature was $34 \pm 1{ }^{\circ} \mathrm{C}$ at the beginning of the experiment and gradually decreased to $24{ }^{\circ} \mathrm{C}$ on $21 \mathrm{st}$ day of the experiment. The amount of consumed feed (feed intake, FI) of birds kept in each pen was daily recorded. The birds were weighted at the end of every week to measure individual body weight (BW). Weight gain (WG) and feed conversion ratio (FCR) were calculated from the weekly FI and $\mathrm{BW}$ values per pen.

The carcass yield, length, and weight of digestive tract (TDT), foregut (esophagus, crop, gizzard, proventriculus), small intestine, ceacae, and colon were measured in three birds from each replicate pen at 21 days of age and in all birds at the age of 42 days.

The ileal contents were collected and centrifuged to obtain supernatants for the measurements of its viscosity using a Brookfield LVTD-CP-40, USA) and its $\mathrm{pH}$ using a digital $\mathrm{pH}$ meter.

The data regarding growth performance was subjected to analysis of variance according to general linear model (GLM) using the SPSS statistical program (SPSS, version 22), in which a least significant difference test $(\mathrm{P}<0.05)$ was applied to the treatment means.

Table 1 - Compositions of basal diet (negative control)

\begin{tabular}{|c|c|c|}
\hline $\begin{array}{l}\text { Percentage of feed material } \\
\left(\mathrm{g} \mathrm{kg}^{-1} \text { as fed }\right)\end{array}$ & $\begin{array}{c}\text { Starter period } \\
\text { (from } 0 \text { to } 21 \text { days } \\
\text { of age) }\end{array}$ & $\begin{array}{l}\text { Grower and finisher } \\
\text { periods } \\
\text { (from } 21 \text { to } 42 \text { days } \\
\text { of age) }\end{array}$ \\
\hline Yellow corn & 300.0 & 400.0 \\
\hline Soybean meal & 250.0 & 213.0 \\
\hline Wheat & 283.0 & 250.0 \\
\hline Vegetable oil & 45.0 & 60.0 \\
\hline Fish meal & 90.0 & 50.0 \\
\hline Calcium carbonate & 10.0 & 9.0 \\
\hline Dicalcium phosphate & 13.0 & 10.0 \\
\hline Salt & 3.0 & 3.0 \\
\hline Vitamin-mineral mixture $^{1}$ & 4.0 & 4.0 \\
\hline DL-methionine & 2.0 & 1.0 \\
\hline \multicolumn{3}{|l|}{ Analyzed nutrient $\left(\mathrm{g} \mathrm{kg}^{-1}\right)$} \\
\hline Dry matter & 889.0 & 900.0 \\
\hline Protein & 230.0 & 200.0 \\
\hline Fat & 67.0 & 59.0 \\
\hline Total fiber & 33.0 & 50.0 \\
\hline $\begin{array}{l}\text { Metabolizable energy }\left(\mathrm{kcal} \mathrm{kg}^{-1}\right) \\
\text { (calculated) }\end{array}$ & 3,122 & 3,250 \\
\hline $\mathrm{Ca}$ (calculated) & 10.0 & 9.0 \\
\hline Available P (calculated) & 5.0 & 4.2 \\
\hline \multicolumn{3}{|c|}{$\begin{array}{l}{ }^{1} \text { A kg of premix provided: vitamin } \mathrm{A}, 5,000,000 \mathrm{IU} \text {; vitamin } \mathrm{D}_{3}, 750,000 \mathrm{IU} \\
\text { vitamin } \mathrm{E}, 25,000 \mathrm{ppm} \text {; vitamin } \mathrm{K}_{3}, 2,000 \mathrm{ppm} \text {; vitamin } \mathrm{B}_{1}, 2,500 \mathrm{ppm} ; \\
\text { vitamin } \mathrm{B}_{2}, 5,000 \mathrm{ppm} \text {; vitamin } \mathrm{B}_{6}, 2,500 \mathrm{ppm} \text {; niacin, } 30,000 \mathrm{ppm} \text {; calcium } \\
\text { D-pantotenate, } 10,000 \mathrm{ppm} \text {; folic acid, } 1,000 \mathrm{ppm} \text {; biotin, } 100 \mathrm{ppm} \text {; Mn, } 37,500 \\
\text { ppm; Fe, } 50,000 \mathrm{ppm} \text {; Zn, } 40,000 \mathrm{ppm} \text { Cu, } 7,500 \mathrm{ppm} \text {; I, } 250 \mathrm{ppm} \text {; Co, } 100 \mathrm{ppm} \text {; } \\
\text { Se, } 100 \mathrm{ppm} \text {. }\end{array}$} \\
\hline
\end{tabular}




\section{Results}

Average moisture content of both SSF batches (YFA and NYFA) at $0 \mathrm{~h}$ of fermentation period was $600 \mathrm{~g} \mathrm{~kg}^{-1}$, which was reduced to $580 \mathrm{~g} \mathrm{~kg}^{-1}$ by the end of $24 \mathrm{~h}$ of fermentation. This is an expected increase in dry matter during the SSF process. The final wet products were dried for $72 \mathrm{~h}$ at room temperature. The moisture levels of both SSF batches did not differ significantly $(\mathrm{P}>0.05)$ at 24,48 , and $72 \mathrm{~h}$. The averaged corresponding moisture contents at 24, 48, and $72 \mathrm{~h}$ were 180,140 , and $100 \mathrm{~g} \mathrm{~kg}^{-1}$, respectively. At $0 \mathrm{~h}$ fermentation, YFA and NYFA products had a $\mathrm{pH}$ of $5.88 \pm 0.5$ and $5.99 \pm 0.3$, respectively, and the corresponding values were reduced to $3.90 \pm 0.7$ in YFA and $4.08 \pm 0.2$ in NYFA product by the end of $24 \mathrm{~h}$ of fermentation. The reduction in the $\mathrm{pH}$ was parallel to the titratable acidity values of both feed additives, which were almost the same, $56 \pm 1.55 \mathrm{~g} \mathrm{~kg}^{-1}$, as compared with the value of $5.0 \pm 0.5 \mathrm{~g} \mathrm{~kg}^{-1}$ of the same substrates at $0 \mathrm{~h}$ of the fermentation period.
There was a significant $(\mathrm{P}<0.05)$ difference in viable yeast counts between the NYFA and YFA. Non-yeast fermented additives have an active yeast count of $3 \times 10^{10} \pm 0.15 \mathrm{cfu} \mathrm{kg}^{-1}$, which was significantly $(\mathrm{P}<0.05)$ higher than that of YFA, measured as $9 \times 10^{8} \pm 0.017 \mathrm{cfu} \mathrm{kg}^{-1}$. Microbial activity was reduced nearly by a $1.0 \log$ in YFA, while YFA was initially inoculated with $9 \times 10^{9} \mathrm{cfu}$ yeast per $\mathrm{kg}$. The differences in viable yeast counts of YFA and NYFA were well reflected on the yeast counts of the diets supplemented with these additives. The diet supplemented with NYFA at $5.0 \mathrm{~g} \mathrm{~kg}^{-1}$ has a $1.52 \times 10^{7} \pm 0.045 \mathrm{cfu} \mathrm{kg}^{-1}$ and the diet supplemented with NYFA at $10.0 \mathrm{~g} \mathrm{~kg}^{-1}$ had a $3.10 \times 10^{7} \pm 0.25 \mathrm{cfu} \mathrm{kg}^{-1}$ active yeast counts, respectively. Similarly, the diet supplemented with YFA at $5.0 \mathrm{~g} \mathrm{~kg}^{-1}$ had a yeast count of $4.55 \times 10^{5} \pm 0.75$ cfu $\mathrm{kg}^{-1}$ and the diets supplemented with YFA at $10.0 \mathrm{~g} \mathrm{~kg}^{-1}$ had a yeast count of $9.20 \times 10^{5} \pm 0.10 \mathrm{cfu} \mathrm{kg}^{-1}$ (Table 2).

The birds fed the test diets had almost similar FI at both 21 and 42 days of age (Table 3), except that the birds fed the diet supplemented with NYFA at $10 \mathrm{~g} \mathrm{~kg}^{-1}$

Table 2 - Active yeast cell counts $\left(\mathrm{cfu} \mathrm{kg}^{-1}\right)$ of the diets supplemented with NYFA and YFA at 5.0 and $10.0 \mathrm{~g} \mathrm{~kg}^{-1}$

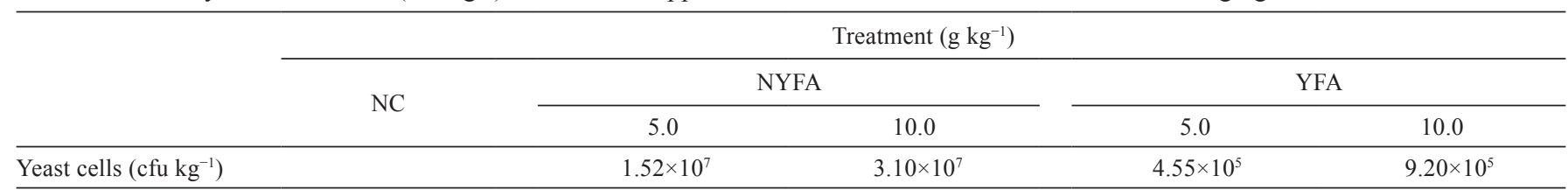

NC - negative control; NYFA - non-yeast fermented additives; YFA - yeast-fermented additives; cfu - colony-forming units.

Table 3 - Effects of NYFA and YFA supplementations at 5.0 and $10.0 \mathrm{~g} \mathrm{~kg}^{-1}$ on body weight, weight gain, feed intake, and feed conversion ratio of birds at the ages of 21 and 42 days

\begin{tabular}{|c|c|c|c|c|c|c|c|}
\hline & \multicolumn{5}{|c|}{ Treatment $\left(\mathrm{g} \mathrm{kg}^{-1}\right)$} & \multirow{3}{*}{ SEM } & \multirow{3}{*}{ P-value } \\
\hline & \multirow{2}{*}{$\mathrm{NC}$} & \multicolumn{2}{|c|}{ NYFA } & \multicolumn{2}{|c|}{ YFA } & & \\
\hline & & 5.0 & 10.0 & 5.0 & 10.0 & & \\
\hline $\mathrm{n}$ & 63 & 63 & 63 & 63 & 63 & - & - \\
\hline \multicolumn{8}{|c|}{ Body weight (g/bird) } \\
\hline Day 0 & 54.7 & 54.8 & 55.0 & 54.2 & 54.5 & 0.5 & 0.172 \\
\hline Day 21 & $907 \mathrm{a}$ & $968 b$ & $964 b$ & $895 a$ & $918 \mathrm{a}$ & 19 & 0.0001 \\
\hline Day 42 & $2276 a$ & $2406 b$ & $2502 b$ & $2286 a$ & $2374 a b$ & 72 & 0.0001 \\
\hline \multicolumn{8}{|c|}{ Weight gain (g/bird) } \\
\hline Day 21 & $852 \mathrm{a}$ & $914 b$ & $909 b$ & $840 \mathrm{a}$ & $863 a$ & 19 & 0.0001 \\
\hline Day 42 & $2221 \mathrm{a}$ & $2351 \mathrm{ab}$ & $2447 b$ & $2232 \mathrm{ab}$ & $2320 \mathrm{ab}$ & 72 & 0.0001 \\
\hline \multicolumn{8}{|c|}{ Feed intake (g/bird) } \\
\hline Day 21 & 1561 & 1569 & 1557 & 1532 & 1519 & 33 & 0.361 \\
\hline Day 42 & 4890 & 4934 & 5088 & 4842 & 4906 & 104 & 0.117 \\
\hline \multicolumn{8}{|c|}{ Feed conversion ratio } \\
\hline Day 21 & $1.83 \mathrm{a}$ & $1.72 b$ & $1.72 b$ & $1.82 \mathrm{a}$ & $1.76 \mathrm{ab}$ & 0.04 & 0.015 \\
\hline Day 42 & $2.20 \mathrm{a}$ & $2.10 \mathrm{~b}$ & $2.08 \mathrm{~b}$ & $2.17 \mathrm{ac}$ & $2.11 \mathrm{bc}$ & 0.03 & 0.003 \\
\hline \multicolumn{8}{|c|}{ Dead } \\
\hline $0-42$ days & 1 & 3 & 3 & 0 & 1 & - & - \\
\hline
\end{tabular}

NC - negative control; NYFA - non-yeast fermented additives; YFA - yeast-fermented additives; SEM - standard error of the mean.

a-c - Different letters indicate significant $(\mathrm{P}<0.05)$ difference between the means of treatment groups. 
numerically increased FI at 42 days of age. Effects of YFA and NYFA on BW, WG, and FCR on broilers were significant $(\mathrm{P}<0.05)$ at 21 st and $42 \mathrm{nd}$ days of experiment (Table 2). Comparing with the values obtained with the birds fed the negative control diet, there was a significant increase $(\mathrm{P}<0.05)$ in $\mathrm{BW}$ and $\mathrm{WG}$ of the birds fed the diets containing NYFA at 5 and $10 \mathrm{~g} \mathrm{~kg}^{-1}$ at the 21 st day and 42nd day. Significantly $(\mathrm{P}<0.05)$ improved $\mathrm{FCR}$ values were obtained from the 21-day-old birds fed diets of NYFA at both supplementation doses, compared with FCR of the birds fed the negative control diet. Similarly, the FCR values of 42-day-old birds fed the diets of NYFA of both doses and the diet supplemented with YFA at $10 \mathrm{~g} \mathrm{~kg}^{-1}$ were remarkably $(\mathrm{P}<0.05)$ higher than the FCR value of birds fed the negative control diet. Furthermore, the number of dead birds fed the different diets was found insignificant in our study (Table 2).

Carcass yield of broilers was not influenced by dietary treatments at the $21 \mathrm{st}$ day (Table 4). But, there was a significant $(\mathrm{P}<0.05)$ reduction in the carcass weight of 42-day-old broilers fed the diet supplemented with NYFA at $10 \mathrm{~g} \mathrm{~kg}^{-1}$.

The weight of TDT was not influenced by the dietary diets at 21 st day of the study, but significantly $(\mathrm{P}<0.05)$ influenced at the 42nd day of this study (Table 4). Of the birds at 42 days old, the birds fed the diet supplemented with NYFA at $5.0 \mathrm{~g} \mathrm{~kg}^{-1}$ and YFA at $10.0 \mathrm{~g} \mathrm{~kg}^{-1}$ had significantly $(\mathrm{P}<0.05)$ reduced weight of TDT. Highest TDT weight was obtained from the birds fed the diet supplemented with NYFA at $10 \mathrm{~g} \mathrm{~kg}^{-1}$. When compared with the negative control diet, all the dietary treatments at the 21 st day of the study and only the diets supplemented with NYFA at $5.0 \mathrm{~g} \mathrm{~kg}^{-1}$ and YFA at $10.0 \mathrm{~g} \mathrm{~kg}^{-1}$ at the $42 \mathrm{nd}$ day of the study caused a significant $(\mathrm{P}<0.05)$ reduction in heart weight. The diet supplemented with NYFA at $5.0 \mathrm{~g} \mathrm{~kg}^{-1}$ significantly $(\mathrm{P}<0.05)$ reduced liver weight as opposed to a significantly increased liver weight $(\mathrm{P}<0.05)$ in the birds fed the diet supplemented with NYFA at $10.0 \mathrm{~g} \mathrm{~kg}^{-1}$, only at the age of 42 days. These effects of treatments were, however, sporadic.

The dietary treatments had a significant $(\mathrm{P}<0.05)$ effect on the lengths of TDT, foregut, and small intestine of broilers at the 42nd day of the study, but not at the 21st day (Table 5). A significant $(\mathrm{P}<0.05)$ and constant reduction in the lengths of various digestive segments (TDT, foregut, small intestine, caeca, and colon) was observed in the birds fed the diets supplemented with NYFA at $5.0 \mathrm{~g} \mathrm{~kg}^{-1}$ as opposed to a significant reduction of these parameters in the birds fed the diet supplemented with NYFA at $10.0 \mathrm{~g} \mathrm{~kg}^{-1}$ at the 42nd day of this study (Table 5). The effects of the diet supplemented with NYFA and YFA at other doses were sporadic, not consistent. In this study, the viscosity and $\mathrm{pH}$ of ileal contents of broilers were not affected by the dietary treatments, although there was an increased ileal viscosity in the broilers fed the diet supplemented with YFA at $10 \mathrm{~g} \mathrm{~kg}^{-1}$ (Table 6).

\section{Discussion}

The SSF in this study lasted for $24 \mathrm{~h}$ by a successful optimization of the fermentation conditions. During SSF, the temperature ranged from 37 to $39^{\circ} \mathrm{C}, \mathrm{pH}$ from 5.0 at $0 \mathrm{~h}$

Table 4 - Effects of NYFA and YFA supplementations at 5.0 and $10.0 \mathrm{~g} \mathrm{~kg}^{-1}$ on carcass yield ( $\mathrm{kg}$ per $100 \mathrm{~kg}$ BW) and weights (g per bird) of total digestive tract (TDT) and digestive organs of birds at days 21 and 42

\begin{tabular}{|c|c|c|c|c|c|c|c|}
\hline & \multicolumn{5}{|c|}{ Treatment $\left(\mathrm{g} \mathrm{kg}^{-1}\right)$} & \multirow{3}{*}{ SEM } & \multirow{3}{*}{ P-value } \\
\hline & \multirow{2}{*}{$\mathrm{NC}$} & \multicolumn{2}{|c|}{ NYFA } & \multicolumn{2}{|c|}{ YFA } & & \\
\hline & & 5.0 & 10.0 & 5.0 & 10.0 & & \\
\hline \multicolumn{8}{|c|}{ Carcass yield } \\
\hline Day 21 & 59.2 & 60.1 & 59.3 & 59.2 & 60.4 & 1.2 & 0.112 \\
\hline Day 42 & $73.8 \mathrm{a}$ & $74.4 \mathrm{a}$ & $71.8 \mathrm{~b}$ & $73.4 \mathrm{ab}$ & $75.0 \mathrm{a}$ & 0.8 & 0.001 \\
\hline \multicolumn{8}{|c|}{ TDT weight } \\
\hline Day 21 & 112.9 & 116.3 & 110.6 & 111.0 & 108.0 & 4.7 & 0.12 \\
\hline Day 42 & $236.5 \mathrm{ab}$ & $220.6 b$ & $258.8 \mathrm{a}$ & $247.0 \mathrm{ab}$ & $226.4 b$ & 14.1 & 0.001 \\
\hline \multicolumn{8}{|c|}{ Heart weight } \\
\hline Day 21 & $6.8 \mathrm{a}$ & $5.9 b$ & $5.7 \mathrm{bc}$ & $5.1 \mathrm{c}$ & $5.6 \mathrm{bc}$ & 0.3 & 0.001 \\
\hline Day 42 & $16.8 \mathrm{a}$ & $14.5 b$ & $17.5 \mathrm{a}$ & $17.5 \mathrm{a}$ & $14.8 \mathrm{ab}$ & 1.0 & 0.001 \\
\hline \multicolumn{8}{|c|}{ Liver weight } \\
\hline Day 21 & 27.9 & 28.0 & 28.6 & 25.8 & 26.4 & 1.4 & 0.65 \\
\hline Day 42 & $57.7 \mathrm{a}$ & $48.0 \mathrm{~b}$ & $63.4 \mathrm{a}$ & $57.0 \mathrm{a}$ & $57.9 \mathrm{a}$ & 2.4 & 0.001 \\
\hline
\end{tabular}

BW - body weight; NC - negative control; NYFA - non-yeast fermented additives; YFA - yeast-fermented additives; SEM - standard error of the mean. a-c - Different letters indicate significant $(\mathrm{P}<0.05)$ difference between the means of treatment groups. 
to around 4.0 and moisture content from 600 to $580 \mathrm{~g} \mathrm{~kg}^{-1}$. The $\mathrm{pH}$ under 5.0 is suitable for inhibition of pathogenic microorganisms. Further decrease in $\mathrm{pH}$ of the fermented substrate was normally caused by the productions of organic acids (Canibe and Jensen, 2003; Canibe et al., 2006), whose levels were significantly high $\left(56 \mathrm{~g} \mathrm{~kg}^{-1}\right)$ in this study. Overall, the results of fermentation parameters in this SSF process were similar to the results obtained previously (Yasar et al., 2016; Yasar and Gok, 2014; Chen et al., 2013).

No increased FI of the birds by the dietary treatments in this study was observed with the supplementations of poultry diets with similar feed additive products, suggesting that the beneficial performance effects of probiotic additives are not regulated by the changes in voluntary feed intake in poultry (Gao et al., 2008; Sarica et al., 2009).
The results of promoted growth rate and improved FCR in the case of diets supplemented with NYFA and YFA in our study were in good agreement with the results reported earlier (Yasar and Desen, 2014; Reisinger et al., 2012; Haldar et al., 2011). On the other hand, there were other studies reporting different results with the use of the same probiotic product in broiler chickens. Although there was no influence of 0.5 and $1.0 \%$ supplementation of a probiotic additive (protexin) neither on growth performance nor on carcass yield in Japanese quails (Ayaşan, 2016), the same additive significantly $(\mathrm{P}<0.05)$ increased the body weight of broiler chickens (Fallah, 2016). This is typically due to the differences between the poultry species; the probiotic feed additives are specifically designed and formulated for each species by the manufacturers.

Table 5 - Length (cm per bird) of total digestive tract (TDT), foregut (esophagus, crop, proventriculus, and gizzard), small intestine, caeca, and colon of birds of 21 and 42 days old fed the negative control diet and the diets supplemented with NYFA and YFA at 5.0 and $10.0 \mathrm{~g} \mathrm{~kg}^{-1}$

\begin{tabular}{|c|c|c|c|c|c|c|c|}
\hline & \multicolumn{5}{|c|}{ Treatment $\left(\mathrm{g} \mathrm{kg}^{-1}\right)$} & \multirow{3}{*}{ SEM } & \multirow{3}{*}{ P-value } \\
\hline & \multirow{2}{*}{$\mathrm{NC}$} & \multicolumn{2}{|c|}{ NYFA } & \multicolumn{2}{|c|}{ YFA } & & \\
\hline & & 5.0 & 10.0 & 5.0 & 10.0 & & \\
\hline Day 21 & 157.5 & 154.8 & 160.9 & 153.4 & 155.8 & 4.9 & 0.85 \\
\hline Day 42 & $209.5 \mathrm{ab}$ & $179.5 \mathrm{c}$ & $221.6 \mathrm{a}$ & $212.6 \mathrm{a}$ & $195.9 \mathrm{~b}$ & 6.9 & 0.001 \\
\hline \multicolumn{8}{|c|}{ Foregut } \\
\hline Day 42 & $23.0 \mathrm{a}$ & $20.0 \mathrm{~b}$ & $23.2 \mathrm{a}$ & $21.7 \mathrm{ab}$ & $20.9 b$ & 0.9 & 0.001 \\
\hline \multicolumn{8}{|c|}{ Small intestine } \\
\hline Day 21 & 126.4 & 123.7 & 130.5 & 123.7 & 124.8 & 5.8 & 0.99 \\
\hline Day 42 & $166.8 \mathrm{ab}$ & $142.6 \mathrm{c}$ & $176.7 \mathrm{a}$ & $171.0 \mathrm{a}$ & $155.9 \mathrm{bc}$ & 7.6 & 0.001 \\
\hline \multicolumn{8}{|c|}{ Caeca } \\
\hline Day 42 & $8.4 \mathrm{ab}$ & $7.3 \mathrm{a}$ & $10.0 \mathrm{c}$ & $10.5 \mathrm{c}$ & $8.9 \mathrm{~b}$ & 0.5 & 0.001 \\
\hline
\end{tabular}

NC - negative control; NYFA - non-yeast fermented additives; YFA - yeast-fermented additives; SEM - standard error of the mean.

a-c - Different letters indicate significant $(\mathrm{P}<0.05)$ difference between the means of treatment groups.

Table 6 - Viscosity (cPs) and pH of ileal contents of birds of 21 and 42 days old fed the negative control diet and the diets supplemented with NYFA and YFA at 5.0 and $10.0 \mathrm{~g} \mathrm{~kg}^{-1}$

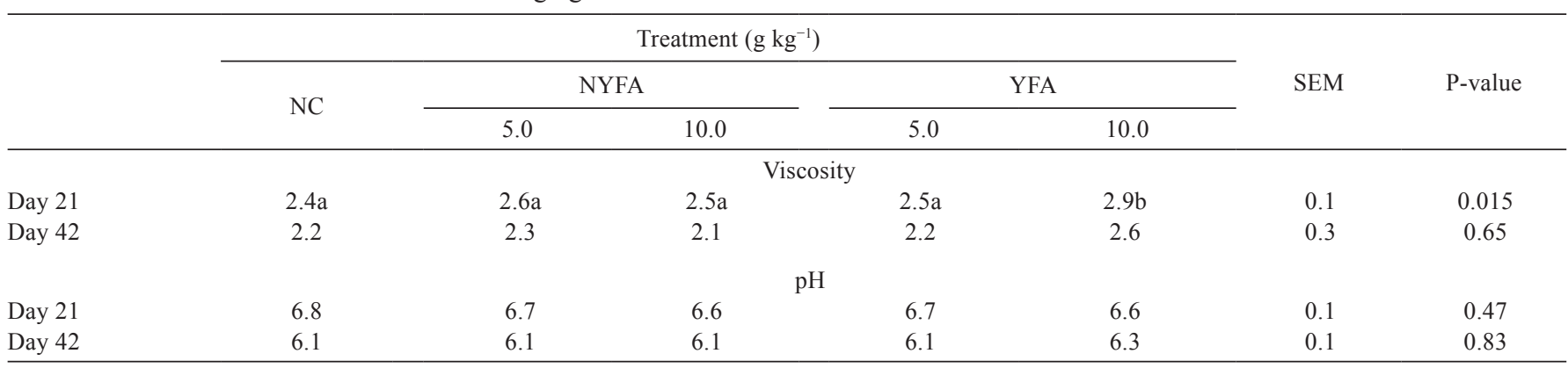

NC - negative control; NYFA - non-yeast fermented additives; YFA - yeast-fermented additives; SEM - standard error of the mean. a-c - Different letters indicate significant $(\mathrm{P}<0.05)$ difference between the means of treatment groups. 
Improved growth rate and FCR in our study seemed to be due to high inclusion levels of NYFA and YFA products. The levels of 5.0 and $10.0 \mathrm{~g} \mathrm{~kg}^{-1}$ were relatively high as compared with the rates tested in previous studies, ranging from 0.45 to $3.0 \mathrm{~g} \mathrm{~kg}^{-1}$ of the diet (Yasar and Desen, 2014; Fasina and Thanissery, 2011; Sarica, et al., 2009; Zhang et al., 2005). On the other hand, improved growth performance was much more associated with the active yeast counts of diets to which the probiotics were added. A kilogram of diet containing yeast probiotic at $2.3 \times 10^{5} \mathrm{cfu}$ (Chen et al., 2009), $1.3 \times 10^{7} \mathrm{cfu}$ (Zhang et al., 2005 ), and $4.3 \times 10^{7} \mathrm{cfu}$ (Shim et al., 2012) were found very effective to induce significant improvements in broiler performance. All the above indicated that the higher yeast counts (up to $10^{9} \mathrm{cfu} \mathrm{kg}^{-1}$ ), the higher performance improvement in broilers (Shim et al., 2012; Kim et al., 2012). Yeast fermented additives were produced by the use of yeast inoculant at $9 \times 10^{9} \mathrm{cfu} \mathrm{kg}^{-1}$ at the start of SSF, while the final dried product of YFA at the end of 24-h fermentation has only an active yeast count of $9 \times 10^{5} \mathrm{cfu}$ $\mathrm{kg}^{-1}$. In contrary, the final product of NYFA, to which no yeast inoculant was initially added, reached to a high active yeast number of $3 \times 10^{7} \mathrm{cfu} \mathrm{kg}^{-1}$ at the end of fermentation. This is normally explained by the fact that the level of yeast inoculation in YFA was already too high and the microbial phase was quickly entered to the dead phase by the end of $24 \mathrm{~h}$, thereby reducing the number of viable cells. Having considered the levels of active yeast counts in the diets, the differences between the diets were well reflected on the bird performance in this study. There were significant improvements both in the growth rate and FCR of the birds fed the diet supplemented with NYFA at 5 and $10 \mathrm{~g} \mathrm{~kg}^{-1}$, whereas there was only a significant improvement in the FCR of the birds fed the diet supplemented with $10 \mathrm{~g} \mathrm{~kg}^{-1}$ of YFA. Furthermore, the fermentation process in this study was done with the help of value-adding co-products, i.e., whey, pomaces of tomato and citrus, and rosemary, which could have added new functionalities to the final products. The fermented feed materials produced from this SSF process were found with high efficacies in broilers due to organic acids, flavoring agents, endogenous enzymes, probiotics, and antioxidants from these co-products (Yasar et al., 2016; Yasar and Gok 2014; Chen et al., 2013; Dhillon et al., 2012, Canibe et al., 2006; Canibe and Jensen, 2003).

Birds fed diets containing yeast probiotics had increased carcass yield and increased weights of digestive organs (gizzard, heart, and liver), despite the reduced abdominal fat (Zhang et al., 2005; Panda et al., 2000; Paryad and Mahmoudi, 2008; Onifade et al., 1998). Contrary to these studies, there were increases in carcass weights of the birds fed the yeast-supplemented diets in our study, except that the diet supplemented with NYFA at $10 \mathrm{~g} \mathrm{~kg}^{-1}$ reduced carcass weight. Nevertheless, the dietary yeast supplementation generally improves carcass yield in broiler chickens, which was well correlated with reduced weights of digestive organs. In our study, the reduced carcass yield by the diet supplemented with NYFA at $10 \mathrm{~g} \mathrm{~kg}^{-1}$ was due to increased weight of TDT. Furthermore, in our study, there were sporadic changes in heart and liver weights affected by the dietary treatments. Similar changes in digestive organ weights were previously reported with the diet fermented with yeast inoculant at $10^{6} \mathrm{cfu}_{\mathrm{kg}^{-1}}$ (Chen et al., 2013, Hossain et al., 2012 Chen et al., 2009). In our study, the changes in digestive organ weights were similarly reflected on the changes in the lengths of entire digestive tract, foregut, and small intestine (Table 5).

The diets with yeast probiotic products had a positive effect on the development of intestinal epithelial region (Adebiyi, et al., 2012; Gao et al., 2008) and improved immune system (Solis de los Santos et al., 2007). These effects were also reported in young growing chicks (Fasina and Thanissery, 2011). Therefore, it can be concluded that improved growth rate and FCR with the diet supplemented with NYFA at $5.0 \mathrm{~g} \mathrm{~kg}^{-1}$ may have been modulated by early maturations of intestinal segments and remained intact. Furthermore, the weight of digestive organs remained relatively low in the birds fed the diets supplemented at the above doses due to an increased growth rate and FCR.

\section{Conclusions}

Supplementing the diets with 5.0 and $10 \mathrm{~g} \mathrm{~kg}^{-1}$ of yeast fermented additives or $5.0 \mathrm{~g} \mathrm{~kg}^{-1}$ of non-yeast fermented additives is highly recommended for enhancing growth rate due to its high level of active yeast cells, while a $10 \mathrm{~g} \mathrm{~kg}^{-1}$ dietary supplementation of non-yeast fermented additives cannot be used due to decreased carcass weights.

\section{Acknowledgments}

We thank the Suleyman Demirel Universitesi Rektörlüğü, Bilimsel Araştırma Projeleri Birimi for financially supporting this study (Project no. 4048-YL2-14).

\section{References}

Adebiyi, O. A.; Makanjuola, B. A.; Bankole, T. O. and Adeyori, A. S. 2012. Yeast culture (Saccharomy cescerevisiae) supplementation: effect on the performance and gut morphology of broiler birds. Global Journal of Science Frontier Research Biological Sciences 12:25-29. 
Ayaşan, T. 2016. Efficacy of probiotic supplementation on growth performance and carcass traits in Japanese quails. Indian Journal of Animal Sciences 86:795-798.

Canibe, N. and Jensen, B. B. 2003. Fermented and non-fermented liquid feed to growing pigs: Effect on aspects of gastrointestinal ecology and growth performance. Journal of Animal Science 81:2019-2031.

Canibe, N.; Virtanen, E. and Jensen, B. B. 2006. Microbial and nutritional characteristics of pig liquid feed during fermentation. Animal Feed Science \& Technology 134:108-123.

Chen, K. L.; Kho, W. L.; You, S. H.; Yeh, R. H.; Tang, S. W. and Hsieh, W. 2009. Effects of Bacillus subtilis var. natto and Saccharomyces cerevisiae mixed fermented feed on the enhanced growth performance of broilers. Poultry Science 88:309-315.

Chen, W.; Zhu, Z. X.; Wang, J. P.; Wang, Z. X. and Huang, Y. Q. 2013. Effects of Bacillus subtilis var. Natto and Saccharomyces cerevisiae fermented liquid feed on growth performance, relative organ weight, intestinal microflora, and organ antioxidant status in Landes geese. Journal of Animal Science 91:978-985.

Chen, C. H.; Chen, S. W. and Wand, H. T. 2016. Effect of supplementation of yeast with bacteriocin and Lactobacillus culture on growth performance, cecal fermentation, microbiota composition, and blood characteristics in broiler chickens. AsianAustralasian Journal of Animal Sciences 30:211-220.

Dębski, B.; Zalewski, W.; Gralak, M. A. and Kosla, K. 2004. Chromium-yeast supplementation of chicken broilers in an industrial farming system. Journal of Trace Elements in Medical \& Biolology 18: 47-51.

Dhama, K.; Latheef, S. K.; Mani, S.; Abdul Samad, H.; Karthik, K.; Tiwari, R.; Ullah Khan, R.; Alagawany, M.; Farag, M. R.; Alam, G. M.; Laudadio, V. and Tufarelli, V. 2015. Multiple beneficial applications and modes of action of herbs in poultry health and production-A review. International Journal of Pharmacology 11:152-176.

Dhillon, G. S.; Kaur, S.; Kaur Brar, S. and Verma, M. 2012. Potential of apple pomace as a solid substrate for fungal cellulase and hemicellulase bioproduction through solid-state fermentation. Industrial Crops and Products 38:6-13.

Fallah, R. 2016. Productive performance, carcass trait and blood parameters of broiler chickens fed different levels of dried whey and protexin probiotic. International Journal of Basic Sciences Applied Research 4:240-247.

Fasina, Y. O. and Thanissery, R. R. 2011. Comparative efficacy of a yeast product and bacitracin methylene disalicylate in enhancing early growth and intestinal maturation in broiler chicks from breeder hens of different ages. Poultry Science 90:1067-1073.

Gao, J.; Zhang, H. J.; Yu, S. H.; Wu, S. G.; Yoon, I.; Quigley, J.; Gao, Y. P. and Qi, G. H. 2008. Effects of yeast culture in broiler diets on performance and immunomodulatory functions. Poultry Science 87:1377-1384.

Haldar, S.; Ghosh, T. K.; Toshiwati and Bedford, M. R. 2011. Effects of yeast (Saccharomyces cerevisiae) and yeast protein concentrate on production performance of broiler chickens exposed to heat stress and challenged with Salmonella enteritidis. Animal Feed Science \& Technology 168:61-71.

Hossain, M. E.; Ko, S. Y.; Kim, G. M.; Firman, J. D. and Yang, C. J. 2012. Evaluation of probiotic strains for development of fermented Alisma canaliculatum and their effects on broiler chickens. Poultry Science 91:3121-3131.

ISO - International Organization for Standardization. 2009. Animal feeding stuffs - Isolation and enumeration of yeast probiotic strains. EN 15789:2009.

Kim, J. S.; Ingale, S. L. and Kim, Y. W. 2012. Effect of supplementation of multi-microbe probiotic product on growth performance, apparent digestibility, cecalmicrobiota and small intestinal morphology of broilers. Journal of Animal Physiology and Animal Nutrition (Berl) 96:618-626.

Nigam, P. S. N and Pandey, A. 2009. Solid-state fermentation technology for bioconversion of biomass and agricultural residues utilization. p.197-223. In: Biotechnology for agro-industrial residues. Singh nee' Nigam, P. and Pandey, A., eds. C Springer Science+Business Media B.V., Dordrecht, Netherlands.

Olnood, C.; Beski, S.; Choct, M. and Iji, P. 2015. Novel probiotics: Their effects on growth performance, gut development, microbial community and activity of broiler chickens. Animal Nutrition 3:194-191.

Onifade, A. A.; Babatunde, G. M.; Afonja, S. A.; Ademola, S. G. and Adesina, E. A. 1998. The effect of a yeast culture addition to a low-protein diet on the performance and carcass characteristics of broiler chickens (Abstract). Poultry Science 77(Suppl. 1):44.

Onifade A. A.; Odunsi A. A. and Babatunde G. M. 1999. Comparison of the supplemental effects of Saccharomyces cerevisiae and antibiotics in low-protein and high-fiber diets fed to broiler chickens. Archiv Fur Tierernahrung 52:29-39.

Panda, A. K.; Reddy, M. R.; Rama Rao, S. V.; Raju, M. L. N. and Paraharaj, N. K. 2000. Growth, carcass characteristics, immune componence and response to Escherichia coli of broiler fed diets with various level of probiotic. Archiv Fur Geflugelkunde 64:152-156.

Paryad, A. and Mahmoudi, M. 2008. Effect of different levels of supplemental yeast (Saccharomyces cerevisiae) on performance, blood constituents and carcass characteristics of broiler chicks. African Journal of Agricultural Research 3:835-842.

Reisinger, N.; Ganner, A.; Masching, S.; Schatzmayr, G. and Applegate, T. J. 2012. Efficacy of a yeast derivative on broiler performance, intestinal morphology and blood profile. Livestock Science 143:195-200

Sarica, S.; Corduk, M.; Yarim, G. F.; Yenisehirli, G. and Karatas, U. 2009. Effects of novel feed additives in wheat based diets on performance, carcass and intestinal tract characteristics of quail. South African Journal of Animal Science 39:144-157.

Shim, Y. H.; Ingale, S. L.; Kim J. S.; Kim, K. H.; Seo, D. K.; Lee, S. C.; Chae, B. J. and Kwon, I. K. 2012. A multi-microbe probiotic formulation processed at low and high drying temperatures: effects on growth performance, nutrient retention and caecal microbiology of broilers. British Poultry Science 53:482-490.

Solis de los Santos, F.; Donoghue, A. M.; Farnell, M. B.; Huff, G. R.; Huff, W. E. and Donoghue, D. J. 2007. Gastrointestinal maturation is accelerated in turkey poults supplemented with a mannanoligosaccharide yeast extract (Alphamune). Poultry Science 86:921-930.

Wang, Y. and $\mathrm{Xu}$, B. 2008. Effect of different selenium source (sodium selenite and selenium yeast) on broiler chickens. Animal Feed Science \& Technology 144:306-314.

Yasar, S. and Desen, D. E. 2014. Efficacy of a feed probiotic bacteria (Enterococcus faecium NCIMB 10415), spore (Bacillus subtilis ATCC PTA-6737) and yeast (Saccharomyces cerevisiae) in Japanese quails. Bulletin UASVM Animal Science and Biotechnology 71:63-70.

Yasar, S.; Gok, M. S. and Gurbuz, Y. 2016. Performance of broilers fed raw or fermented and re-dried wheat, barley and oats grains. Turkish Journal of Veterinary \& Animal Sciences 40:313-323.

Yasar, S. and Gok, M. S. 2014. Fattening performance of Japanese quails (Coturnix coturnix japonica) fed on diets with high levels of dry fermented wheat, barley and oats grains in whey with citrus pomace. Bulletin UASVM Animal Science and Biotechnology 71:51-62.

Zhang, A. W.; Lee, B. D.; Lee, S. K.; Lee, K. W.; An, G. H.; Song, K. B. and Lee, C. H. 2005. Effects of yeast (Saccharomyces cerevisiae) cell components on growth performance, meat quality and ileal mucosa development of broiler chicks. Poultry Science 84:1015-1021 